Milton Vasques Thibau de Almeida ${ }^{1}$ Ana Cristina de Melo Silveira ${ }^{2}$
Recebido em: 30/10/2014.

Aprovado em: 13/05/2015.

1 Possui graduação em Direito pela Universidade Federal de Minas Gerais (1979), especialização em Direito do Trabalho (1984), mestrado em Direito Civil (1989) e doutorado em Direito Constitucional (2001) pela mesma Universidade. Foi bolsista da CAPES na Faculdade de Direito da Universidade de Lisboa (1995). Atualmente é Desembargador do Tribunal Regional do Trabalho da 3a. Região (Minas Gerais), Professor dos cursos de graduação em Direito e em Medicina (Core Curriculum II: Estado, Sociedade e Ciência Política), da Universidade de Itaúna. Professor do programa de mestrado em Direito da Universidade de Itaúna, na linha de pesquisa "Constitucionalismo Social: Fundamentos, Políticas Públicas e Privadas de Proteção Social Nacional, Comunitária e Internacional". Professor Associado II de Direito do Trabalho e Previdência Social da Faculdade de Direito da Universidade Federal de Minas Gerais. Tem experiência na área do Direito, com ênfase em Direito do Trabalho, Teoria Geral do Estado, Direito Empresarial, Direito Previdenciário, Política da Seguridade Social e Efetividade dos Direitos Humanos.

2 Mestranda de Direitos Fundamentais do Curso de Mestrado em Direito da Universidade de Itaúna.

\section{As situações jurídicas de proteção social, a judicialização da sua efetivação e o ativismo judicial*}

\section{Resumo}

O ativismo judicial constitui instrumento relevante da ética judicial no fenômeno da judicialização dos direitos sociais ao amparo social nas áreas de ação da seguridade social. O presente artigo se propõe a analisar os aspectos relevantes do ativismo judicial a partir da gênese dos direitos sociais e apontar suas características e eficácias, e, ao final, enfatizar o ativismo judicial trabalhista.

Palavras-chave: Seguridade social. Saúde. Assistência social. Previdência social. Judicialização de direitos sociais. Ativismo judicial. Complementação de aposentadoria. Mercado de Previdência. Mercado de Pensões.

\begin{abstract}
The social rights ougtht to be recognizes by the constitucion or by the laws. When the social security institutions refused to give the social benefits to its destinatary, those persons has to submit the final decision to the Judiciary Power. By this way emerges the judicial activism, that recomends to the judges, as ethical behavior, to guide its decisions towards the constitutional rules, in the moment of the interpretation of laws, or to aplicate directly its principles, in the social rights field. There is, somehow, a movement of resistance over the judicial activism, that aimes the depreciation of the power of its members.
\end{abstract}

Keywords: Social security. Health. Pensions. Judicialism. Complementary benefits. Pension's Market. 


\section{Introdução}

Desde meados do século XVIII o Estado Medieval passou a assumir a responsabilidade pelas ações de assistência social, ampliando o Estado Moderno essa participação na questão social ao instituir a previdência social na Alemanha, em 1883, até, ao final, assumir uma responsabilidade ainda mais ampla, a partir de 1935, com a promulgação da lei do seguro social norteamericana (Social Security Act), pela execução de um conjunto de ações de proteção social nas áreas que definem um sistema de seguridade social.

Naturalmente que as razões que conduziram o Estado a assumir essas responsabilidades são variadas, mas todas elas têm em comum um fundamento de política pública. Nem sempre, porém, o Estado se mantém fiel às diretrizes que ele próprio se determinou, numa época em que a proteção social não era assunto para ser tratado numa constituição, ou que lhe foram determinados pelas constituições sociais, a partir da constituição mexicana de 1917.

As posturas do Estado oscilam, conforme a época e o lugar, entre ser mais pródigo com a proteção social ou ser mais austero com a tutela das pessoas necessitadas, por último tendo adotado uma postura de resistência à efetivação de direitos na área da seguridade social que compeliu a população rumo à efetivação judicial dos seus supostos direitos subjetivos públicos sonegados, num movimento denominado de "judicialização".

Objetivamos, pois, examinar algumas causas e consequências da conflituosidade existente entre as políticas públicas e as expectativas dos cidadãos ao amparo social prometido pelo sistema da seguridade social.

\section{A tipificação legal das situações sociais de risco social no sistema da seguridade social}

O Estado, ao assumir a responsabilidade pela gestão da proteção social e ao instituir autarquias da administração pública direta para executar as ações de proteção social, passou a legislar sobre os diversos sistemas e regimes compreendidos no campo de ação da seguridade social, quais sejam, a saúde, a assistência social e a previdência social ${ }^{1}$ (artigo 194, caput, da Constituição da Re-

BRASIL. Constituição (1988). Constituição da República Federativa do Brasil. Disponível em: <http:/www.planalto.gov.br/ccivil_03/constituicao/constituicaocompilado. htm>. Acesso em: 07 jul. 2015. pública Federativa do Brasil promulgada em 1988).

A definição dos riscos sociais cobertos na área de ação da previdência social difere daqueles que são inerentes às áreas de ação da saúde e da assistência social, em virtude das exigências feitas no campo da previdência social, que é guiada pela técnica atuarial, que é inerente aos seguros sociais, e que são inexistentes nas áreas de ação da saúde e da assistência social, cujas coberturas não estão fundamentadas no seguro social, daí porque dispensam os destinatários das suas proteções de serem previamente conhecidos (listagem, cadastramento ou inscrição) e de serem responsáveis pelo financiamento do sistema protetivo.

Essa distinção já se faz presente aos olhos dos especialistas, ao olharem para o rol dos princípios jurídicos fundamentais da seguridade social, listados no artigo 194, parágrafo único, da Constituição da República Federativa do Brasil promulgada em 1988, podendo ser reparado que todos aqueles que fazem alusão a segurados, financiamento e benefícios são princípios de previdência social, pois nas áreas de saúde e de assistência social não os há.

\subsection{A tipificação legal das situações sociais de risco na área da previdência social}

As situações sociais de risco são definidas atuarialmente na área de ação da previdência social de conformidade com as diretrizes traçadas pelo princípio jurídico da seletividade e da distributividade na prestação dos benefícios e serviços (artigo 194, parágrafo único, inciso III, da constituição brasileira de 1988)², que estabelece a premissa de que, sendo limitados os recursos financeiros do sistema de previdência social, o Estado deve adotar um critério de seleção dos riscos sociais a serem cobertos pelo seguro social, que leve em consideração a prioridade da cobertura dos riscos sociais mais urgentes em detrimento daqueles menos urgentes, ao mesmo tempo em que estabelece requisitos para definir a distribuição dos benefícios e serviços ("prestações") aos segurados e dependentes mais necessitados, através do estabelecimento dos requisitos necessários à aquisição do direito subjetivo público à proteção social.

BRASIL. Constituição (1988). Constituição da República Federativa do Brasil. Disponível em: <http:/www.planalto.gov.br/ccivil_03/constituicao/constituicaocompilado. htm>. Acesso em: 07 jul. 2015. 
Surgem, pois, os tipos legais de proteção social na área de ação da previdência social, os denominados "tipos previdenciários".

Os tipos previdenciários se agrupam para formar os regimes e os sistemas de previdência social.

Celso Barroso Leite $^{3}$ esclarece que, em princípio um regime integra um sistema, ao menos do ponto de vista da organização administrativa da área social, ao passo que sistema pressupõe a existência de mais de um regime, observando que na letra expressa da Constituição, o todo (seguridade social) é menos sistema do que uma de suas partes (o Sistema Único de Saúde), e que um sistema de seguridade social só existe indiretamente no texto constitucional e um sistema de previdência social não figura expressamente na Constituição ou na legislação. Por outro lado, regime é parte e sistema o todo, o que é uma conceituação que não é tão tranquila como pode parecer, mas que faz sentido, pois nas suas origens regime significa normas e diretrizes, e sistema significa conjunto organizado, inclusive de regimes, e que, por isso, as entidades internacionais e a Associação Internacional de Seguridade Social contornam essa questão polêmica utilizando as expressões "esquema de previdência social" ou "programa de previdência social".

Um regime de previdência social é constituído, do ponto de vista atuarial, pela definição dos riscos sociais a serem cobertos (plano de benefícios), pela definição das suas fontes de financiamento (plano de custeio) e pela instituição de um órgão gestor.

Tudo isto é definido por lei: a lei do plano de benefícios, a lei do plano de custeio e a criação do órgão gestor (ou, ao menos, a atribuição da gestão a uma entidade gestora já existente).

As leis que instituem esses regimes de previdência social devem atender às exigências mínimas impostas pela Convenção no 102, de 1952, da OIT - Organização Internacional do Trabalho, também conhecida como "Norma Mínima de Previdência", que exige que, para que um regime de previdência social seja reconhecido como tal deve dispor no seu plano de benefícios, ao menos, das proteções sociais básicas da aposentadoria e da pensão, e

\footnotetext{
LEITE, Celso Barroso. Dicionário enciclopédico de previdência social. São Paulo: LTR, 1996. p. 137-138.

4 ORGANIZAÇÃO INTERNACIONAL DO TRABALHO. Convenção n.102, de 28 de junho de 1952. Normas Mínimas da Seguridade Social. Disponível em: <http://www.oitbrasil.org.br/node/468>. Acesso em: 07 jul. 2015.
}

que deve oferecer a assistência médica ao menos para os trabalhadores.

A lei é a única fonte de direitos na área da previdência social, desde a observância da referida Convenção Internacional e da Constituição brasileira de 1988, descendo pela hierarquia das leis até chegar no plano interno da regulamentação do INSS - Instituto Nacional do Seguro Social, não havendo espaço para a ingerência de qualquer das fontes não-estatais de Direito.

Nos planos de benefícios a lei parte do princípio da seletividade para definir os riscos sociais a serem cobertos pelo regime jurídico de previdência social, instituindo tipos legais (os "tipos previdenciários") que descrevem hipoteticamente as situações jurídicas da proteção social previdenciária.

Da mesma forma como ocorre no âmbito do direito punitivo do Estado, também ocorre na seara do direito protetivo, pois só haverá proteção social se houver uma lei anterior que defina a cobertura do risco social e estabeleça os requisitos para a sua distribuição, assim como os níveis em que essa proteção social será concedida, observando a proposta atuarial.

Não há proteção social no âmbito da previdência social sem lei anterior que defina a cobertura de um determinado risco social, nem há direito subjetivo público ao atendimento sem que a lei defina, com antecedência, quais são os requisitos para a sua aquisição e os limites atuariais da sua concessão.

Os segurados ou os dependentes destinatários da proteção previdenciária adquirem o direito subjetivo público ao atendimento ao implementarem, concomitantemente, todas as situações fáticas descritas no tipo legal previdenciário, que são, basicamente, três: a) a vinculação trabalhista, que é a permanente vinculação a uma atividade de trabalho que o enquadre como segurado obrigatório, ou a uma ocupação que o enquadre como segurado facultativo do regime geral da previdência social, ou, em outras palavras, a manutenção do vínculo previdenciário; b) o cumprimento da carência, que corresponde ao nível mínimo de contribuições sociais devidas pelo segurado para financiar o benefício previdenciário reivindicado, havendo benefícios que dispensam carência, assim como benefícios que demandam carências curtas e outros que exigem carências longas; c) a verificação do risco social, também conhecido como infortúnio, que correspondem ao sinistro no campo dos seguros privados. 


\subsection{A tipificação legal das situações sociais de risco nas áreas da saúde e da assistência social}

As áreas de saúde e de assistência social, por serem universalizadas, isto é, por dispensarem a participação dos seus destinatários no financiamento da proteção social e, até mesmo, a identificação prévia desses destinatários (listagem ou cadastramento), demanda menos rigor legislativo na definição dos direitos subjetivos públicos a serem cobertos. Da forma como a Constituição da República de 1988 a eles se refere, como sendo "um direito de todos" (artigo 196) ${ }^{5}$ ou como sendo devida "a quem dela necessitar" (artigo 203, caput), isso cria uma falsa expectativa de que as ações de saúde e de assistência social são ilimitadas. Em alguns casos, as leis infraconstitucionais que regulamentam tais preceitos constitucionais, que são, respectivamente, a Lei Orgânica da Saúde (Lei no 8.080, de 19/09/1990) e a Lei Orgânica da Assistência Social (Lei $\mathrm{n}^{\circ}$ 8.742, de 07/12/1993) criam limitações de acesso ou exclusões de conteúdos protetivos.

Essas limitações ocorrem, geralmente, na área da saúde, pela baixa taxa de transferência de recursos orçamentários destinados ao financiamento das ações do Sistema Único de Saúde, como já se tornou de conhecimento geral, tendo sido uma das reivindicações populares levadas para as ruas em várias capitais e cidades do interior durante a Copa das Confederações, em meados de 2013.

As alegações de carência de recursos orçamentários e a discricionariedade das escolhas dos agravos de saúde, das técnicas de diagnóstico, das técnicas de tratamento, e da listagem da assistência medicamentosa, compõem as estratégias das políticas públicas para a área de saúde, e estão perfeitamente encasteladas em certas disposições da Lei Orgânica da Saúde ${ }^{6}$, a exemplo da listagem oficial das doenças originadas dos processos de trabalho (artigo 6, inciso VII, da LOS) ${ }^{7}$ e da elaboração de normas para regular as atividades de serviços privados

5 BRASIL. Constituição (1988). Constituição da República Federativa do Brasil. Disponível em: <http://www.planalto.gov.br/ccivil 03/constituicao/constituicaocompilado. htm>. Acesso em: 07 jul. 2015.

$6 \quad$ BRASIL. Lei no 8.080, de 19 de setembro de 1990. Dispõe sobre as condições para a promoção, proteção e recuperação da saúde, a organização e o funcionamento dos serviços correspondentes e dá outras providências. Disponível em: <http://www.planalto.gov.br/ccivil_03/leis/L8080.htm>. Acesso em: 07 jul. 2015.

BRASIL. Lei $n^{\circ}$ 8.080, de 19 de setembro de 1990. Disponível em: <http://www.planalto.gov.br/ccivil_03/leis/L8080. htm>. Acesso em: 07 jul. 2015. de saúde (artigo 15, inciso IX, da LOS) ${ }^{8}$, aonde a discricionariedade administrativa tanto pode atuar para ampliar, quanto para restringir, o campo de ação da saúde, fazendo sobrepor o interesse público sobre a necessidade social, gerando, pois, a busca da solução pela via judicial, movimento que já ficou conhecido como "judicialização da saúde", dentro de outras judicializações possíveis.

A aquisição do direito subjetivo público às ações de saúde e de assistência social não dependem tanto do cumprimento de exigências impostas por tipos legais, mas onde a legislação infraconstitucional cria exclusões ou limitações de atendimentos, surgem situações conflitivas que, se não forem resolvidas pelas vias administrativas próprias da Lei Orgânica da Saúde ou da Lei Orgânica da Assistência Social, também deverão ser resolvidas perante o Poder Judiciário, engrossando, desta forma, a torrente da "judicialização" das demandas sociais reprimidas ou não atendidas.

$\mathrm{Na}$ área de saúde, a situação jurídica é definida inicialmente pela própria Constituição da República ${ }^{9}$, de 1988. A denominada "saúde social", que corresponde à área de ação da saúde na seguridade social, é caracterizada por ações de reparação das enfermidades e dos agravos de saúde, a despeito de não dispensar as políticas públicas de prevenção, e, portanto, só adquirem o direito subjetivo público ao atendimento o cidadão que tiver sido acometido pela doença, ou, no mínimo, que tiver suspeitas de ter sido acometido por alguma doença com evidências fundamentadas por sintomas que possam conduzir a um provável diagnóstico positivo. O Sistema Único de Saúde não cobre e nem atende ações de medicina preventiva $\mathrm{e}$ nem de diagnóstico precoce.

$\mathrm{Na}$ área da assistência social o direito subjetivo público é genericamente definido pela Constituição da República, de 1988, como sendo devido "a quem dela necessitar" (artigo 203, caput), estando, portanto, direcionadas à cobertura das necessidades dos cidadãos carentes, que são basicamente os miseráveis e os indigentes.

BRASIL. Lei no 8.080, de 19 de setembro de 1990. Disponível em: <http://www.planalto.gov.br/ccivil_03/leis/L8080. htm>. Acesso em: 07 jul. 2015.

$9 \quad$ BRASIL. Constituição (1988). Constituição da República Federativa do Brasil. Disponível em: <http://www.planalto.gov.br/ccivil_03/constituicao/constituicaocompilado. htm>. Acesso em: 07 jul. 2015. 


\section{A premência do reconhecimento adminis- trativo dos direitos subjetivos públicos dos destinatários da proteção social}

No campo do direito penal, não basta a consumação do crime ou da contravenção penal para que se deflagre imediatamente a punição do Estado, sendo necessária a provocação do Estado para que a aplique de ofício (representação penal) ou a requerimento (queixa crime), sendo necessária a mobilização da jurisdição administrativa através de um procedimento (o inquérito policial), para a verificação da ocorrência de todos os elementos de definição do crime, tais como a autoria, a materialidade, a tipicidade, a imputabilidade, etc.. O mesmo ocorre no campo do direito previdenciário, também não bastando a ocorrência do risco social para deflagrar automaticamente a aquisição do direito ao benefício previdenciário, sendo necessário ao segurado ou ao dependente formular o pedido de concessão do benefício perante a via administrativa própria do INSS - Instituto Nacional do Seguro Social, através de um procedimento (a justificação administrativa), na qual terá que comprovar a verificação dos requisitos necessários à aquisição do direito ao benefício.

A aquisição do direito subjetivo público ao benefício previdenciário não dispensa a sua requisição pela via administrativa, a despeito de não ser exigível a exaustão da jurisdição administrativa para que o interessado possa ter acesso à jurisdição judicial. Por isso, em direito processual previdenciário, o exercício do direito de ação está condicionado a uma situação litigiosa específica, que é o indeferimento do requerimento formulado pelo segurado ou pelo dependente, ou, ao menos, a demora injustificada na tramitação desse requerimento pela autarquia previdenciária, colocando em risco a subsistência dos mesmos.

A constante escalada do indeferimento de requerimentos formulados administrativamente pelos segurados, dependentes e cidadãos que procuram o atendimento das ações da seguridade social fez surgir a judicialização dessas demandas reprimidas, pois os interessados começaram a buscar amparo judicial às suas pretensões resistidas pelas autarquias que integram o organograma da seguridade social, propiciando, desta forma, a escalada crescente do ativismo judicial.

\section{A judicialização dos direitos à saúde, à assis- tência social e à previdência social}

A partir da compreensão da gênese dos direitos subjetivos públicos às ações da seguridade social, podemos traçar um diagnóstico sucinto sobre a judicialização dos direitos sociais, ante às resistências opostas pelos órgãos gestores das áreas de ação da saúde, da assistência social e da previdência social.

Existem algumas resistências desses órgãos gestores que são justificadas, pois nem sempre o segurado, o dependente ou o cidadão possui o direito subjetivo público ao atendimento da seguridade social. Mas existem outras situações jurídicas nas quais o indeferimento do benefício não tem justificativa e descumprem preceitos de direitos fundamentais.

Significa, portanto, que a judicialização abrange uma multiplicidade de ações judiciais interpostas contra o Poder Público, nas quais a resistência à concessão do benefício: a) é justificada pela autarquia previdenciária (por decorrerem de um indeferimento secundum legem); b) é discutível (por versar sobre uma dúvida razoável quanto ao alcance e à interpretação das leis de saúde, de assistência social e de previdência social); c) é indiscutivelmente injustificada (por ser despida de fundamentação legal e/ ou contrariar preceitos de direitos fundamentais).

Podemos classificar essas espécies de judicialização, quanto aos seus objetivos, em: judicialização pedante, judicialização interpretativa e judicialização impositiva.

\subsection{A judicialização pedante}

A judicialização pedante é baseada no ajuizamento das ações que já são, desde a sua origem, desprovidas de fundamento legal, não raro constituindo mera aventura jurídica.

Atribuímos esse o rótulo de pedante, porque nela o segurado, o dependente ou o cidadão pretende obter o direito ao recebimento ao benefício sem que tal lhe seja assegurado por lei, pelo que ela força a barra, para assim, forçar um pronunciamento judicial que lhe possa lhe vir a ser favorável.

No processo do trabalho esse tipo de procedimento corresponde a uma prática processual habitual (usus fori), que é conhecido como "se cola", tal como "jogar barro na parede": o autor reclamante pede o que quer, mesmo que o pedido não tenha respaldo em fundamento de fato ou de direito, para ver "se cola", como alguém que 
"joga barro na parede", pois "se colar, colou"; se não colar, valeu a tentativa de se obter um acordo judicial mais vantajoso ou uma sentença judicial mais favorável diante do inflacionamento dos pedidos, que alternam pedidos que são devidos e pedidos que não são devidos, porque o réu pode não comparecer à audiência e ser condenado à revelia (o sistema de citação postal da Justiça do Trabalho é reconhecidamente suscetível a falhas), ou pode não contestar satisfatoriamente os pedidos, por não ter prestado atenção a algum detalhe, ou a alguns dos pedidos, pois, não raro, o elenco dos pedidos em inúmeros processos trabalhistas vai de "a" a " $\mathrm{z}$ ", e quando termina o alfabeto, a numeração dos pedidos continua em " $\mathrm{z} 1$ ", " $\mathrm{z} 2$ ", " $\mathrm{z} 3$ " e, assim, sucessivamente, de vez que o procedimento da reclamação trabalhista admite um cúmulo indeterminado de pedidos relativos a obrigações das mais variadas naturezas, todas elas sendo, direta ou indiretamente, consideradas como matérias trabalhistas quando têm gênese na relação de emprego ou com ela se relacionem, na forma disposta pelos incisos I a IX, do artigo 114, da Constituição Federal ${ }^{10}$ de 1988 (com a redação que lhes foi dada pela Emenda Constitucional no 45 , de 2004). Se o réu reclamado não contestar ou se o Juiz aceitar a argumentação e o pedido, o que não existia como obrigação por lei ou por contrato, passa a existir por constituição judicial em acordo ou em sentença, em decorrência do descumprimento do ônus processual da impugnação especificada, conforme dispõe o artigo 302, caput, segunda parte, do CPC de 1973 (com equivalência no artigo 341 do novo CPC de 2005) ${ }^{11}$.

Não é difícil, portanto, entender como essa praxis trabalhista adentrou os umbrais da Justiça Comum e da Justiça Federal em matéria de saúde, de assistência social e de previdência social.

Os direitos sociais da área da seguridade social, com especial destaque para os direitos previdenciários, não comportam interpretação ampliativa e nem restritiva, porquanto: a) uma interpretação ampliativa quebraria a previdência social, por impor um aumento de despesa sem a correspondente fonte de custeio total, violando os

10 BRASIL. Constituição (1988). Emenda constitucional n. 45, de 30 de dezembro de 2004. Disponível em: <http://www. planalto.gov.br/ccivil_03/constituicao/Emendas/Emc/ emc45.htm>. Acesso em: 07 jul. 2015.

11 BRASIL. Lei $n^{\circ} 11.187$, de 19 de outubro de 2005. Disponível em: <http://www.planalto.gov.br/ccivil_03/_ato20042006/2005/lei/l11187.htm>. Acesso em: 07 jul. 2015. preceitos dos artigos 40, caput, e 201, caput, da Constituição Federal ${ }^{12}$ de 1988, que exigem a preservação do seu equilíbrio financeiro e atuarial; b) uma interpretação restritiva negaria a proteção social, propiciando que a previdência social se transformasse num sistema de mera arrecadação tributária sem cumprir a finalidade para a qual os benefícios previdenciários foram instituídos, que é a de promover a cobertura e o atendimento universal preconizado pelo princípio jurídico proclamado no artigo 194, parágrafo único, inciso I, da mesma Constituição.

Por isso na área da previdência social aplica-se o critério da legalidade estrita: está na lei tem direito; não está na lei não tem direito.

Essa espécie de judicialização visa impor o império do sentimentalismo sobre as razões práticas da Ciência do Direito e da técnica atuarial que preside a administração dos regimes de previdência social.

Como, na maioria das vezes, o segurado, o dependente e o cidadão não tem nada a perder, ele pede um provimento judicial sabendo de antemão da pouca ou nenhuma chance de obter uma decisão favorável, mas insiste, tenta, noafã de obter alguma vantagem.

Na década de 1990, Raul Portanova ${ }^{13}$ escreveu um artigo na Revista de Previdência Social narrando a existência de cerca de 330 tipos de fraude catalogadas pela previdência social, e concluiu que se mesmo sendo baixos os valores das aposentadorias e das pensões no Regime Geral da Previdência Social, isso representa o prestígio que a previdência social tem perante os pobres e miseráveis, que ainda assim lutam, até com desonestidade, para alcançar o direito ao benefício a qualquer custo.

Não é essa a espécie de judicialização que vem interessando à doutrina, só tendo relevância para efeitos estatísticos dentro da organização interna do Poder Judiciário, porque promovem, desnecessariamente, o inchaço da máquina judiciária. Contudo, o Poder Judiciário não existe apenas para julgar as lides, pois também administra as ações judiciais como instrumentos de pacificação social mesmo quando o resultado negativo já seja previsível. É o efeito psicológico do processo, pois permite aos

BRASIL. Constituição (1988). Constituição da República Federativa do Brasil. Disponível em: <http://www.planalto.gov.br/ccivil_03/constituicao/constituicaocompilado. htm>. Acesso em: 07 jul. 2015.

13 PORTANOVA, Raul. A grande fraude da previdência. Revista de Previdência Social, São Paulo, v. 15, n. 18, p. 416421, jul. 1991. 
cidadãos extravasarem ou amenizarem as suas angústias usando o processo como divã e o Juiz como clínico das tensões econômicas e sociais.

\subsection{A judicialização interpretativa}

A judicialização interpretativa é aquele que está calcada numa dúvida razoável sobre o alcance e a interpretação das leis sociais.

Os servidores dos órgãos gestores da seguridade social não estão autorizados a atribuir interpretação alguma a qualquer dos preceitos legais relativos aos benefícios nas áreas de saúde, de assistência social e de previdência social, por isso as leis de previdência social são massantes, repetitivas e enfadonhas, justamente para objetivar o preenchimento de todas as hipóteses interpretativas, para não deixar lacunas e omissões.

No plano interno do órgão gestor do regime geral da previdência social - o Instituto Nacional do Seguro Social (INSS) - existe uma profusão de Instruções, Circulares, etc, assim como os precedentes das Juntas de Recursos da Previdência Social, órgão competente para exercer a jurisdição administrativa, que atribuem as interpretações que a própria Administração Pública atribui às leis previdenciárias, notadamente a Lei do Plano de Custeio da Seguridade Social (Lei $n^{\circ} 8.212$, de 24/07/1991), a Lei do Plano de Benefícios da Previdência Social (Lei $n^{\circ}$ 8.213, de 24/07/1991) e o Regulamento da Previdência Social (Decreto no 3.048, de 06/05/1999).

A despeito de quase não haver margem para dúvidas interpretativas sobre o alcance e a extensão das normas jurídicas de previdência social, ainda assim é possível lançar alguns questionamentos interpretativos sobre elas, notadamente no que se refere à sua inconstitucionalidade, também sendo possível questionar judicialmente as exclusões e as limitações impostas aos acessos dos cidadãos aos procedimentos de saúde e à assistência medicamentosa impostas pela regulamentação interna dos órgãos gestores da saúde.

Nesse campo da judicialização não falta fundamento às decisões administrativas emanadas dos órgãos gestores da seguridade social, mas a interpretação que estes atribuem às leis sociais não encontra respaldo jurídico diante das garantias de direitos proclamadas pelos princípios constitucionais e pelas leis sociais, por pretenderem impor a primazia do interesse público sobre a necessidade social amparada por lei.

É evidente que, no campo do direito administra- tivo, o interesse público da Administração Pública se sobrepõe aos interesses privados e aos interesses coletivos (a exemplo do que estatui o artigo $8^{\circ}$, caput, da Consolidação das Leis do Trabalho - Decreto Lei no 5.854, de 01/05/1943), mas o interesse social é maior do que o interesse público.

A jurisprudência dos Superior Tribunal de Justiça e dos Tribunais Regionais Federais já pacificou o entendimento de que, em matéria previdenciária, o INSS, autarquia da Administração Pública da União, apenas administra um patrimônio que pertence à sociedade.

A previdência social deve ser administrada com visos ao cumprimento dos seus objetivos de proteção social e não como uma empresa que devesse dar lucro.

O então Presidente Itamar Franco, ao dar posse ao Ministro da Previdência Social, Sérgio Cuttolo, determinou-lhe que cumprisse a Constituição da República "até o último centavo", conforme este declarou de público no I Seminário Nacional de Previdência Complementar, São Paulo, 1994, e não faltou dinheiro para fechar as contas da previdência social.

Alguns anos após, durante o mandato do Presidente Luís Inácio Lula da Silva, o primeiro Ministro que nomeou para a pasta da Previdência Social, o Senador Amir Lando, ao assumir esse cargo, ficou abismado com o que viu ao pisar no Ministério em apreço pela primeira vez, pois constatou que a burocracia interna do Ministério que iria dirigir tratava a previdência como se fosse uma empresa que devesse dar lucro. Determinou, então, aos seus assessores de confiança que providenciassem o estabelecimento de um convênio com uma instituição de ensino superior de Direito para poder ofertar cursos de reciclagem à distância, em matéria previdenciária, para todos os servidores da previdência social no Brasil. Foi escolhida a Faculdade de Direito da Universidade Federal de Minas Gerais (UFMG), devido à posição geográfica do Estado de Minas Gerais e por se tratar de uma Instituição Federal de Ensino, o que facilitaria o estabelecimento desse convênio, que acabou por não ser celebrado, pois a implantação do seu projeto dependia da disponibilização de um link para as transmissões televisivas, o que atrasou a sua conclusão e, nesse meio tempo, Sua Excelência foi premido por circunstâncias políticas a se afastar do Ministério da Previdência, inviabilizando a concretização do almejado convênio. Mas restou comprovado na prática que o Ministério da Previdência não trata com apreço a proteção social que lhe é confiada. 
Obviamente que a previdência social não deve ser administrada para dar prejuízo, mas também não deve ser administrada para dar lucro, impondo-se que seja administrada nos limites da previsão atuarial para efetivar os seguros sociais que integram o seu Plano de Benefícios, e que, convenhamos, são minguados, mínimos mesmo - o mínimo dos mínimos - se comparado com a previdência social de outros países, especialmente se comparado com os regimes da previdência social portuguesa, que administra um universo de segurados muito menor do que o da previdência social brasileira, e tem menos recursos orçamentários disponíveis do que o nosso Regime Geral da Previdência Social.

O problema da previdência social brasileira não é o alardeado deficit público, é gerencial, conforme concluiu a CPI da Previdência, em 1991, que foi presidida pelo então Deputado Federal Antônio Brito, e que, posteriormente, foi nomeado Ministro da Previdência Social, no governo do Presidente Itamar Franco. Essa CPI, que é uma das poucas que chegou a um resultado, concluiu que o problema da previdência social brasileira não é orçamentário, mas gerencial.

Guy Sorman, citado por Zeno Simm ${ }^{14}$, também afirma que o problema da previdência social brasileira é a má gestão, embora parta de uma outra consideração: a de que esta estaria em crise por causa do neoliberalismo.

Essa espécie de judicialização interessa à doutrina, estando, pois, assentada sobre o indeferimento de requerimentos de concessão de benefícios pelo INSS, quando este usa os argumentos de escassez de recursos orçamentários ou argumentos de natureza técnica ou de conveniências da sua discricionariedade para não cumprir o que a lei determina.

\subsection{A judicialização impositiva}

A judicialização impositiva objetiva impor aos órgãos da Administração Pública gestores da seguridade social o cumprimento dos direitos fundamentais assegurados por lei ou por princípios constitucionais.

É a espécie mais gravosa de judicialização dos direitos sociais, pois, nela, a Administração Pública desafia a superioridade da constituição, negando ou deturpando os princípios jurídicos que asseguram no plano constitucio-

14 SORMAN, Guy apud SIMM, Zeno. Os direitos fundamentais e a seguridade social. São Paulo: LTR, 2005. p. 111. nal a proteção social nas áreas de ação da seguridade social.

No julgamento do Agravo Regimental no Recurso Extraordinário no 271.286, a 2a. Turma do Excelso Supremo Tribunal Federal, sendo Relator o Exmo. Ministro Celso de Mello, foi decidido que a interpretação da norma programática não pode transformá-la em promessa constitucional inconsequente, assim dispondo em sua ementa:

Seguridade Social. Saúde. Hermenêutica. Constitucional. A interpretação da norma programática não pode transformá-la em promessa constitucional inconsequente. CF/88, art. 196.

O caráter programático da regra inscrita no art. 196 da CF/88 - que tem por destinatários todos os entes políticos que compõem, no plano institucional, a organização federativa do Estado brasileiro - não pode converter-se em promessa constitucional inconsequente, sob pena de o Poder Público, fraudando justas expectativas nele depositadas pela coletividade, substituir, de maneira ilegítima, o cumprimento de seu impostergável dever, por um gesto irresponsável de infidelidade governamental ao que determina a própria Lei Fundamental do Estado. ${ }^{15}$

Nesse sentido, Zeno Simm ${ }^{16}$ observa que:

[...] é sabido que as Constituições garantem não apenas os direitos nela arrolados, como também devem assegurar os princípios, fundamentos e instituições que ela, implícita ou explicitamente, reconhece e adota. Muitos desses princípios e instituições são mesmo anteriores à própria Constituição e a qualquer outro sistema de positivação das regras de conduta. E aqui se enquadra a Seguridade Social como instituição, ainda que aquela denominação só tenha lhe sido atribuída mais recentemente, o que, todavia, não lhe retira o caráter de anterioridade $\mathrm{e}$ supremacia.

Muitas críticas têm sido tecidas contra o Poder Judiciário pelos demais poderes da República, por causa do ativismo judicial, que é uma consequência da judicialização de vários aspectos da vida social, mas nunca presenciei algum que partisse da sociedade ou dos jurisdicionados, que vêm no Poder Judiciário um baluarte da efetividade das garantias constitucionais de direitos.

Não se pode perder de vista que o Poder Judiciário é uma das frações da divisão do poder soberano do Estado, a ele sendo atribuída como função principal o exercício da jurisdição judicial, mas exercendo múltiplas

15 Ementa $n^{\circ}$ 19. SABATOVSKI, Emílio; FONTOURA, Iara (Coord). Seguridade social nos tribunais. Curitiba: Juruá, 2004. p. 8.

16 SIMM, Zeno. Os direitos fundamentais e a seguridade social. São Paulo: LTR, 2005. p. 117. 
outras funções que lhe são inerentes como poder de Estado. Dentre elas está o de legislar no processo, para criar a solução do caso concreto (julgamento praeter legem) nas hipóteses em que não hajam normas de lei ou de contrato, ou quaisquer outras fontes de direito que possam ser aplicadas na solução da lide. Não lhe é, portanto, estranha a missão de efetivar direitos sociais assegurados por princípios jurídicos constitucionais sonegados nas instâncias administrativas internas das autarquias da administração da seguridade social responsáveis pela concessão do atendimento das ações de proteção social nas áreas da saúde, da assistência social e da previdência social.

Vigora, portanto, o princípio jurídico da supremacia da Constituição mesmo diante dos interesses públicos da Administração do Estado.

A Constituição não deve ser interpretada de forma a atender aos programas de governo, ao contrário, estes é que devem se moldar à Constituição, afirmou o então Ministro Presidente do Excelso Supremo Tribunal Federal, Sepúlveda Pertence.

\section{0 ativismo judicial frente aos direitos sociais}

Já ficou nas páginas desbotadas da História do Direito o tempo em que os juízes só atuavam mediante provocação para que o processo pudesse tramitar para diante. Frederico Marques registrou, na doutrina do processo civil, que o juiz era igual a um relógio, que precisava de corda para funcionar, e que cabia aos advogados das partes provocá-lo por petição para que ele atuasse até o fim de cada fase processual.

$O$ processo do trabalho (que na sua origem era um procedimento de jurisdição administrativa) nunca conheceu essa realidade descrita pela doutrina do processo civil, pois, desde a sua origem, a Justiça do Trabalho é plasmada pelo princípio dispositivo, pelo qual a jurisdição só precisa ser ativada uma única vez, pois o ajuizamento da ação depende da iniciativa do trabalhador reclamante ("nemo iudicio sine actore"), a partir daí se desenvolvendo por impulso oficial do Juiz do Trabalho, que ainda tem o poder jurisdicional de tomar a iniciativa das provas, razão pela qual não cabe no processo do trabalho a prescrição intercorrente ${ }^{17}$, a despeito do entendimento jurisprudencial uniforme da Súmula n 327 do

BRASIL. Tribunal Superior do Trabalho. Súmula n. 114. Disponível em: <http://www.trtsp.jus.br/geral/tribunal2/ TST/Sumulas.htm>. Acesso em: 07 jul. 2015.
Excelso Supremo Tribunal Federal, justamente porque o Juiz do Trabalho tem o dever de impulsionar o processo ex officio. No entanto, a prescrição intercorrente é cabível e aplicada pela Justiça do Trabalho no procedimento dos Executivos Fiscais ${ }^{18}$, para as execuções das contribuições previdenciárias e das multas aplicadas pela Administração do Trabalho. No processo de execução não só pode como deve ser iniciado de ofício pelo Juiz do Trabalho, conforme determina o artigo 878, caput, da Consolidação das Leis do Trabalho, assim como também determina diretamente a Constituição Federal no artigo 114, item VIII (com a redação que lhe foi dada pela Emenda Constitucional no 45 , de 2004) ${ }^{19}$, relativamente à execução das contribuições previdenciárias incidentes sobre as parcelas de natureza salarial nos acordos e as sentenças proferidas nos processos de competência da Justiça do Trabalho.

De certa forma, a Justiça do Trabalho já vem aplicando o ativismo judicial há muitos anos, de forma intuitiva, face aos desníveis existentes entre os trabalhadores e as empresas, mas agora, com muito mais razão, o fazem até mesmo por orientação da ética da magistratura.

A prestação jurisdicional, na atualidade, é plasmada por uma orientação ética específica do Poder Judiciário, no sentido da formação do "bom juiz", necessário para exercer a jurisdição dentro dos estreitos limites das garantias de direitos dos litigantes.

As políticas judiciais internas dos Tribunais Superiores brasileiros, assim como do CNJ - Conselho Nacional de Justiça, e da Cúpula Iberoamericana do Judiciário, implementaram códigos de ética judicial a serem seguidos pelos magistrados, a partir do Código Modelo de Ética Judicial elaborado pela Cúpula Iberoamericana.

Dentre os deveres éticos da magistratura está a adoção do ativismo positivo (o ativismo negativo é deplorado), que rompe com o ideal bonapartista do juiz asséptico ou eunuco, como afirma Artur César de Souza ${ }^{20}$, estimulando a parcialidade positiva do juiz, consistindo

BRASIL. Lei $n^{\circ}$ 6.830, de 22 de setembro de 1980. Disponível em: <http://www.planalto.gov.br/CCIVIL_03/leis/ L6830.htm>. Acesso em: 07 jul. 2015.

19 BRASIL. Constituição (1988). Emenda constitucional n. 45, de 30 de dezembro de 2004. Disponível em: <http://www. planalto.gov.br/ccivil_03/constituicao/Emendas/Emc/ emc45.htm>. Acesso em: 07 jul. 2015.

20 SOUZA, Artur César de. La parcialidad positiva del juez: fundamento ético material del Código Modelo Iberoamericano. Universitas: Revista de Filosofia, Derecho y Política, Madrid, n. 16, p. 157-181, jul. 2012. 
num princípio de estruturação democrática do Poder Judiciário nas Repúblicas Democráticas Iberoamericanas um "mandato de otimização" - com o objetivo de efetivar materialmente os princípios fundamentais previstos nas constituições democráticas e sociais, segundo os valores e os fins consignados nos textos constitucionais. Em outras palavras, se trata da realização pragmática, no âmbito do Poder Judiciário, do constitucionalismo social e das constituições democráticas.

$\mathrm{O}$ ativismo judicial opera com o mesmo entusiasmo nos vários ramos do Poder Judiciário, contudo, é pouco mencionado na Justiça do Trabalho, onde, de certa forma, não é novidade, mas é de crucial relevância na prestação jurisdição aplicada pelos demais Tribunais, especialmente a Justiça Federal e a Justiça Comum, quanto litígios que versam sobre a efetivação dos direitos sociais à saúde, à assistência social e à previdência social.

Júlio Cesar Garcia Ribeiro ${ }^{21}$ aponta para a existência de uma campanha difamatória e neoliberal que visam impor limitações às prerrogativas do Poder Judiciário, sustentáculo básico do Estado Democrático de Direito, mediante a introdução de mecanismos específicos, tais como a súmula vinculante e a supressão do controle difuso da constitucionalidade, o que atinge em cheio a independência dos juízes e dos próprios Tribunais Estaduais, e visam a implementação da verticalização da função jurisdicional na cúpula, citando ${ }^{22}$, para se referir a uma militarização da estrutura interna da magistratura, e Cármen Lúcia Antunes Rocha ${ }^{23}$, para quem a "deseconomização" do Estado pode significar a "dessocialização" do direito e a desumanização dos princípios constitucionais.

Essas ações dessa política desconstrutiva das prerrogativas dos membros do Poder Judiciário são bastante evidentes, e, ao menos na área dos direitos sociais, com os frequentes questionamentos de inconstitucionalidade das Súmulas do Tribunal Superior do Trabalho, notadamente as de $\mathrm{n}^{\circ} \mathbf{3 6 3}$, que proclamava a nulidade dos contratos celebrados por servidores públicos contratados pela Ad-

21 RIBEIRO, Júlio César Garcia. A previdência social do regime geral na Constituição Brasileira. São Paulo: LTR, 2001. p. 34-35.

22 COSTA, Maria Isabel apud RIBEIRO, Júlio César Garcia. A previdência social do regime geral na Constituição Brasileira. São Paulo: LTR, 2001.

23 ROCHA, Cármen Lúcia Antunes apud RIBEIRO, Júlio César Garcia. A previdência social do regime geral na Constituição Brasileira. São Paulo: LTR, 2001. ministração Pública sem concurso público, e de no 331 , em cujo item IV, está assentada a responsabilidade jurídica subsidiária da empresa tomadora de serviços em relação aos créditos trabalhistas inadimplidos pela devedora principal, que é a empresa intermediária, nas hipóteses em que sejam lícitas as intermediações de mão-de-obra, e que foi questionada pela Administração Pública em face da disposição do artigo 71 da Lei das Licitações ${ }^{24}$, desse questionamento perante o Excelso Supremo Tribunal Federal resultando o acréscimo do item V à referida Súmula $\mathrm{n}^{\circ} 331$ do TST, determinando que seja apurado na instrução processual a culpa in eligendo e a culpa in vigilando da Administração Pública tomadora de serviços.

Certamente que as decisões do Excelso Supremo Tribunal Federal razoavelmente atendam aos interesses da Administração Pública mas não estão à disposição dos interesses empresariais ou dos grupos econômicos, porém, em determinado caso resvalou em proveito dos interesses privados do "Mercado de Previdência" (na expressão de Gérard Lyon-Caén) ou do "Mercado de Pensões" (na expressão de Monereo Pérez), como se nos afigurou no julgamento da relevância geral no processo de recurso extraordinário no 586456, pelo Excelso Supremo Tribunal Federal, em 20 de fevereiro de 2013, ocasião em que foi determinada a competência da Justiça Comum para apreciar e julgar as complementações de aposentadoria.

Essa decisão de relevância geral impôs, sem qualquer exceção (salvo aqueles processos em que já havia julgamento proferido até a data da sua publicação), atingindo até mesmo as aposentadorias instituídas por regulamento de empresa, e que são denominadas pelo direito comparado como "concessões diretas" ou "regimes patronais" ("prevvidenza azziendale" na Itália, "prévoyance d'entreprise" na França, e "book reserve” na Inglaterra).

Como efeito colateral nefasto para o ativismo judicial trabalhista, foi decretada a desconstrução de cerca de quatro décadas de construção jurisprudencial elaborada pelas Súmulas do Tribunal Superior do Trabalho, e que contaram no passado com a participação do mesmo Excelso Supremo Tribunal Federal, cuja jurisprudência, até então, traçava a nítida entre as complementações de aposentadoria advindas dos regimes de previdência complementar e aquelas fundamentadas no direito do trabalho.

24 BRASIL. Lei no 8.666, de 21 de junho de 1993. Disponível em: <http://www.planalto.gov.br/CCIVIL_03/leis/ L8666cons.htm>. Acesso em: 07 jul. 2015. 
Essa decisão suprema implica, ainda que não desejada pelo órgão de cúpula do Poder Judiciária, como um freio ao ativismo judicial trabalhista, e colabora, ainda que de forma involuntária, para uma proteção privilegiada aos interesses dos patrões em detrimento do equilíbrio contratual das relações jurídicas trabalhistas, anulando os avanços sociais preconizados pelo caput do artigo $7^{\circ} \mathrm{da}$ Constituição da República.

Monereo Pérez, citado por Zeno Simm²5, adverte para a existência de uma "concorrência interativa" no relacionamento entre o Estado e o mercado no sistema de pensões (aposentadoria, no direito espanhol) nos países desenvolvidos, e que "a expansão simultânea da Seguridade Social e dos mecanismos de provisão privada a partir do segundo pós-guerra mundial reflete essa interação de sistemas, e a realidade de ambos os sistemas são relativamente intercambiáveis", em decorrência dos baixos valores dos benefícios concedidos pelo Poder Público, o que vem incrementando um aumento do papel e dos percentuais das provisões no setor privado (isto é, das complementações de aposentadoria).

A previdência complementar nasceu dentro das empresas, como um ramo da securitização acessória dos riscos sociais cobertos pelas prestações básicas da previdência social, por isso tem uma dificuldade imensa de se desapegar da sua origem trabalhista, pois ainda hoje tem como pressuposto a "vinculação trabalhista" dos participantes, que só podem ser empregados das empresas patrocinadoras. Em síntese é o que estatui o artigo 202, $\$ 2^{\circ}$, da Constituição Federal de 1988 (com a redação que lhe foi dada pela Emenda Constitucional n² 20, de 1998), ao nosso ver mal interpretado e aplicado pelo Excelso Supremo Tribunal Federal no julgamento do mencionado recurso extraordinário, pois se o contrato de previdência complementar não se confunde com o contrato de trabalho, é evidente que a recíproca é verdadeira, assim como a aposentadoria continua sendo matéria trabalhista, como assegura o artigo 7º, inciso XXIV, da mesma Constituição, razão pela qual pode ser objeto de concessões diretas por parte do empregador, via regulamentos de empresa, cujas condições aderem ao contrato individual de trabalho (como o próprio Excelso STF reconheceu e proclamou inúmeras vezes no passado), desde que objetivem a

25 SIMM, Zeno. Os direitos fundamentais e a seguridade social. São Paulo: LTR, 2005. p. 113. melhoria da condição social dos trabalhadores, conforme assegura o princípio protetor (“pro operario”) proclamado no caput do mesmo artigo $7^{\circ}$ da mesma Constituição, que é o mais fundamental princípio jurídico do direito do trabalho.

\section{Conclusão}

Os direitos subjetivos públicos à proteção social gerida pela seguridade social, nas suas áreas de saúde, de assistência social e de previdência social, estão solidamente assegurados por princípios constitucionais.

As garantias ao amparo de saúde e de assistência social já são proclamadas de forma ampla e direta pela Constituição Federal, no entanto podendo sofrer exclusões e limitações no âmbito regulamentar interno dos órgãos de gestão encarregados de executar as ações de saúde e de assistência social, forçando os cidadãos destinatários dessas tutelas existenciais buscarem amparo judicial perante o Poder Judiciário.

Um pouco diverso, porém não tanto diferente, ocorre com as garantias de amparo social na área da previdência social, onde os direitos subjetivos públicos são definidos em tipos legais (os “tipos previdenciários”), que estabelecem os riscos sociais a serem cobertos e as fontes de custeio dos regimes de previdência social, fundamentados na técnica atuarial, o que implica em não poder ser interpretada a lei previdenciária de forma ampliativa e nem de forma restritiva.

Constatamos a divisão da judicialização em três vertentes (a judicialização pedante, a judicialização interpretativa e a judicialização impositiva), cada uma delas sendo caracterizadas por aspectos próprios, que são peculiares ao tipo de postura adotado como fundamentação pelas autarquias gestoras da saúde, da assistência social e da previdência social, sendo duas delas dotadas de interesse doutrinário e terceira possuindo apenas relevância para efeitos estatísticos na administração interna dos Tribunais.

A judicialização dos direitos sociais atrai o ativismo judicial, que, se foi olhado com desconfiança no passado, hoje é regra de conduta ética da magistratura, recomendada pelo Código Modelo de Ética Judicial elaborado pela Cúpula Iberoamericana do Poder Judiciário, da qual o Brasil participa, assim como no plano interno pelas políticas judiciais implantadas no mesmo sentido pelo Conselho Nacional de Justiça e pelos Tribunais Superiores. 
Certo é, porém, que o Excelso Supremo Tribunal Federal freou parcialmente o ativismo judicial da Justiça do Trabalho, em prol de uma supremacia do interesse da Administração Pública no julgamento das arguições de inconstitucionalidade opostas contra as Súmulas $n^{\circ} 331$, item IV, e no 363, do Tribunal Superior do Trabalho.

\section{Referências}

BRASIL. Constituição (1988). Constituição da República Federativa do Brasil. Disponível em: <http://www.planalto.gov.br/ccivil_03/constituicao/constituicaocompilado. htm>. Acesso em: 07 jul. 2015.

BRASIL. Constituição (1988). Emenda constitucional $n$. 45, de 30 de dezembro de 2004. <http://www.planalto.gov. br/ccivil_03/constituicao/Emendas/Emc/emc45.htm >. Acesso em: 07 jul. 2015.

BRASIL. Lei $n^{\circ}$ 6.830, de 22 de setembro de 1980. Disponível em: <http://www.planalto.gov.br/CCIVIL_03/leis/ L6830.htm>. Acesso em: 07 jul. 2015.

BRASIL. Lei $n^{\circ}$ 8.080, de 19 de setembro de 1990. Disponível em: <http://www.planalto.gov.br/ccivil_03/leis/ L8080.htm>. Acesso em: 07 jul. 2015.

BRASIL. Lei no 8.666, de 21 de junho de 1993. Disponível em: <http://www.planalto.gov.br/CCIVIL_03/leis/ L8666cons.htm>. Acesso em: 07 jul. 2015
BRASIL. Lei $n^{\circ} 11.187$, de 19 de outubro de 2005. Disponível em: <http://www.planalto.gov.br/ccivil_03/_ato20042006/2005/lei/l11187.htm>. Acesso em: 07 jul. 2015.

BRASIL. Tribunal Superior do Trabalho. Súmula n. 114. Disponível em: <http://www.trtsp.jus.br/geral/tribunal2/ TST/Sumulas.htm>. Acesso em: 07 jul. 2015

LEITE, Celso Barroso. Dicionário enciclopédico de previdência social. São Paulo: LTR, 1996.

ORGANIZAÇÃO INTERNACIONAL DO TRABALHO. Convenção n.102, de 28 de junho de 1952. Normas Mínimas da Seguridade Social. Disponível em: <http://www. oitbrasil.org.br/node/468>. Acesso em: 07 jul. 2015.

PORTANOVA, Raul. A grande fraude da previdência. Revista de Previdência Social, São Paulo, v. 15, n. 18, p. 416-421, jul. 1991.

RIBEIRO, Júlio César Garcia. A previdência social do regime geral na Constituição Brasileira. São Paulo: LTR, 2001.

SABATOVSKI, Emílio; FONTOURA, Iara (Coord). Seguridade social nos tribunais. Curitiba: Juruá, 2004.

SIMM, Zeno. Os direitos fundamentais e a seguridade social. São Paulo: LTR, 2005.

SOUZA, Artur César de. La parcialidad positiva del juez: fundamento ético material del Código Modelo Iberoamericano. Universitas: Revista de Filosofia, Derecho y Política, Madrid, n. 16, p. 157-181, jul. 2012. 